\title{
Sintering of MSWI fly ash by microwave energy
}

\author{
Sun-Yu Chou, Shang-Lien Lo*, Ching-Hong Hsieh, Ching-Lung Chen
}

Research Center for Environmental Pollution Prevention and Control Technology, Graduate Institute of Environmental Engineering, National Taiwan University, 71 Chou-Shan Road, Taipei 106, Taiwan, ROC

\section{A R T I C L E I N F O}

\section{Article history:}

Received 18 December 2007

Received in revised form 7 May 2008

Accepted 25 June 2008

Available online $\mathrm{xxx}$

\section{Keywords:}

Microwave energy

MSWI fly ash

Sinter

\begin{abstract}
A B S T R A C T
This study presents the sintering of municipal solid waste incineration (MSWI) fly ash assisted by microwave energy. The composition of fly ash was investigated by chemical sequential extraction and modified microwave digestion method. Effects of process time, container materials, aging time and salt contents were also discussed. The major elements of fly ash are $\mathrm{Ca}, \mathrm{Cl}, \mathrm{Na}, \mathrm{Si}, \mathrm{K}, \mathrm{Al}, \mathrm{Mg}$, and $\mathrm{Zn}$, and the metal species, $\mathrm{Zn}, \mathrm{Cr}, \mathrm{Pb}, \mathrm{Ca}$, and $\mathrm{Cu}$, are mainly in the oxide phase. Under microwave processing, the fly ash was sintered into a glass-ceramics and the leaching concentrations of heavy metals were restrained. The stabilization efficiency increased with an increase in processing time in most of the cases. Better stabilization efficiency of fly ash was discovered by using the $\mathrm{SiO}_{2}$ or $\mathrm{Al}_{2} \mathrm{O}_{3}$ container than by using the graphite plate/SiC plate. The presence of salt in the fly ash could enhance the sintering and stabilization of fly ash. During the aging time of 0-30 days, negligible $\mathrm{Pb}$ in the sintered fly ash was leached out, and the leaching concentration was lower than the criterion.
\end{abstract}

(C) 2008 Elsevier B.V. All rights reserved.

\section{Introduction}

Municipal solid waste incineration (MSWI) fly ash is a residue found in waste after incineration. Fly ash in Taiwan amounts to about 160,000 tons/year. MSWI fly ash is regarded as hazardous waste. The components of MSWI fly ash are complex and unfixed [1]. Major contents are soluble salts [2], $\mathrm{CaO}, \mathrm{SiO}_{2}, \mathrm{Al}_{2} \mathrm{O}_{3}, \mathrm{Fe}_{2} \mathrm{O}_{3}$, $\mathrm{MgO}, \mathrm{Na}_{2} \mathrm{O}, \mathrm{K}_{2} \mathrm{O}, \mathrm{P}_{2} \mathrm{O}_{5}, \mathrm{TiO}_{2}, \mathrm{MnO}, \mathrm{CuO}, \mathrm{ZnO}, \mathrm{PbO}, \mathrm{Cr}_{2} \mathrm{O}_{3}$, and $\mathrm{SO}_{3}$. Minor contents are $\mathrm{Zn}, \mathrm{Pb}, \mathrm{Cr}, \mathrm{Cd}, \mathrm{Cu}, \mathrm{Sn}, \mathrm{Ba}, \mathrm{Sb}, \mathrm{Zr}, \mathrm{As}, \mathrm{Co}, \mathrm{Mo}, \mathrm{Rb}, \mathrm{Bi}$, $\mathrm{V}, \mathrm{Ce}, \mathrm{Ga}, \mathrm{La}, \mathrm{Nd}, \mathrm{Nb}$, and $\mathrm{Hg}$ [3]. TCLP leaching of the heavy metals from MSWI fly ash still results in leachate concentrations above the legal limit for land disposal. Hence, it is important to dispose of this troublesome substance thoroughly before it is sent to landfills. The most commonly used treatment method for MSWI fly ash is cement solidification. However, this method increases the volume of ash, which reduces the useful lifetime of landfill sites. This study aims to find a new method to dispose of fly ash and avoid the disadvantage of cement solidification.

Although microwave heating was introduced over 50 years ago, its use in the treatment of MSWI fly ash is relatively new. Microwave energy is a nonionizing electromagnetic radiation with frequencies in the range of $300 \mathrm{MHz}$ to $300 \mathrm{GHz}$. Compared with other conventional thermal treatment technologies, the microwave technique with its characteristics of polar oscillation and effect of dielectric losses offers the advantage of selective, uniform, and rapid heating.

\footnotetext{
* Corresponding author. Tel.: +886 2 23625373; fax: +886223928821.

E-mail address: sllo@ntu.edu.tw (S.-L. Lo).
}

The interaction of dielectric materials with electromagnetic radiation in the microwave range results in energy absorbance as heat [4].

The application of microwave radiation is widely used in many fields, including sintering and joining of ceramics [5-7], synthesis of composites [7], contaminated soil remediation [8], waste treatment [9,10], mineral processing [11], assisted digestion procedures [12], drying or dewatering of materials, polymer curing, and regeneration of activated carbon [10]. Moreover, a growing interest in the stabilization and immobilization of metal ions in soil and sludge through microwave radiation has also been reported. Results indicated that microwave radiation inhibits the leaching of metal ions from soil or sludge and that it makes these solid wastes acceptable for disposal or recycling [13-15].

This project aims to investigate the sintering of MSWI fly ash by microwave radiation. The objective of this study is to: (1) determine the proper procedure for stabilization of MSWI fly ash by microwave energy, (2) discuss the effects of processing time, (3) compare the effects of different crucibles/containers on microwave radiation of MSWI fly ash, and (4) discuss the effect of soluble salts and caustic substances on microwave radiation.

\section{Materials and methods}

Two specimens of MSWI fly ash from two different incineration plants were tested in this study. The MSWI fly ash was pretreated by drying in an oven at $105^{\circ} \mathrm{C}$ (about $24 \mathrm{~h}$ ), until the mass maintained a constant value within $\pm 1 \%$. 
The composition of the MSWI fly ash was determined by modified microwave digestion method reported in previous studies [15]. Samples of the MSWI fly ash $(0.2 \mathrm{~g})$ were mixed with a $\mathrm{HNO}_{3}-\mathrm{HCl}-\mathrm{HF}$ solution $(3 \mathrm{~mL})$. These acidic slurries were processed using the following two-stage microwave program: (1) $650 \mathrm{~W}$ for $10 \mathrm{~min}$ (final temperature $160^{\circ} \mathrm{C}$ ) and (2) $800 \mathrm{~W}$ for $15 \mathrm{~min}$ (final temperature $200^{\circ} \mathrm{C}$ ). After the microwave-assisted digestion process, the mixtures were cooled to room temperature and filtrated, and the filtrate was adjusted to $100 \mathrm{~mL}$ before analysis.

Modified chemical sequential extraction [16] was also conducted to determine the phase of heavy metals in the MSWI fly ash. Portions of fly ash of $2 \mathrm{~g}$ were put in PVC tubes and mixed with extracting agents. The extraction procedure was as follows:

(i) Exchangeable. The fly ash was extracted at $25^{\circ} \mathrm{C}$ with $8 \mathrm{~mL}$ of magnesium chloride solution ( $1 \mathrm{M} \mathrm{MgCl}_{2}, \mathrm{pH} 7.0$ ) and shaken for $1 \mathrm{~h}(125 \mathrm{rpm})$.

(ii) Bound to carbonates. The residue from (i) was leached at $25^{\circ} \mathrm{C}$ with $8 \mathrm{~mL}$ of $1 \mathrm{M} \mathrm{NaOAc}$ adjusted to $\mathrm{pH} 5.0$ with acetic acid (HOAc). It was continuously shaken for $5 \mathrm{~h}$ (125 rpm).

(iii) Bound to $\mathrm{Fe}-\mathrm{Mn}$ oxides. The residue from (ii) was extracted with $20 \mathrm{~mL}$ of $0.04 \mathrm{M} \mathrm{NH}_{2} \mathrm{OH}-\mathrm{HCl}$ in $25 \%$ (v/v) HOAc. This was performed at $96 \pm 3^{\circ} \mathrm{C}$ with $6 \mathrm{~h}$ shaking ( $\left.125 \mathrm{rpm}\right)$.

(iv) Bound to organic matter. The residue from (iii) was added to $3 \mathrm{~mL}$ of $0.02 \mathrm{M} \mathrm{HNO}_{3}$ and $5 \mathrm{~mL}$ of $30 \% \mathrm{H}_{2} \mathrm{O}_{2}$ adjusted to $\mathrm{pH} 2$ with $\mathrm{HNO}_{3}$, and the mixture was heated to $85 \pm 2{ }^{\circ} \mathrm{C}$ for $2 \mathrm{~h}$ with shaking (125 rpm). A second 3- $\mathrm{mL}$ of $30 \% \mathrm{H}_{2} \mathrm{O}_{2}$ (pH 2 with $\mathrm{HNO}_{3}$ ) was then added and the sample was heated again to $85 \pm 2{ }^{\circ} \mathrm{C}$ for $3 \mathrm{~h}$ with intermittent shaking ( $125 \mathrm{rpm}$ ). After cooling, $5 \mathrm{~mL}$ of $3.2 \mathrm{M} \mathrm{NH}_{4} \mathrm{OAc}$ in $20 \%(\mathrm{v} / \mathrm{v}) \mathrm{HNO}_{3}$ was added and the sample was diluted to $20 \mathrm{~mL}$ and shaken continuously for $30 \mathrm{~min}$.

(v) Residue. The residue from (iv) was digested with a $10-\mathrm{mL}$ of $10 \% \mathrm{HF}$ and $10 \mathrm{~mL} \mathrm{HC}^{\circ} \mathrm{O}_{4}$ mixture at $25^{\circ} \mathrm{C}$ with $1 \mathrm{~h}$ shaking (125 rpm).

Between each successive extraction, separation was effected by centrifuging at $10,000 \mathrm{rpm}$ for $30 \mathrm{~min}$. The resulting solution was filtered though a membrane filter $(0.45 \mu \mathrm{m})$ and analyzed by inductively coupled plasma-atomic emission spectrometry (ICP-AES), whereas the residue was washed with $8 \mathrm{~mL}$ of deionized water; after centrifugation for $30 \mathrm{~min}$, this second supernatant was discarded.

In the sintering experiments, $20 \mathrm{~g}$ samples of fly ash were put in an $\mathrm{SiO}_{2}$ ceramic crucible, $\mathrm{Al}_{2} \mathrm{O}_{3}$ ceramic crucible $(11 \mathrm{~cm}$ diameter), and SiC plate with graphite plate, and the moisture contents were adjusted to $75 \mathrm{wt} . \%$ with deionized water. The experiments were conducted with microwave frequency of $2.45 \mathrm{GHz}$ at $600 \mathrm{~W}$. Respective process times were $10,20,30,40$, and $50 \mathrm{~min}$. The effects of process time, container type, and aging time were discussed. Moreover, the effect of salt in the fly ash under microwave radiation was also studied. The fly ash was pre-washed by deionized water with liquid to solid ratio (L/S) of $5,10,15$, and $20 \mathrm{~mL} / \mathrm{g}$ and followed by the microwave process.

The raw fly ash and treated samples were tested by TCLP and the leaching concentrations were analyzed by ICP-AES. The crystal structure of fly ash samples before and after microwave processes were also determined by X-ray diffraction (XRD) to determine the species variation.

\section{Results and discussion}

\subsection{Chemical composition of MSWI fly ash}

Microwave-assisted digestion was performed for analysis of the chemical composition of MSWI fly ash. Table 1 lists the extractable
Table 1

Chemical composition of MSWI fly ash

\begin{tabular}{lrl}
\hline Elements $(\mathrm{mg} / \mathrm{kg})$ & Plant A & Plant B \\
\hline $\mathrm{Zn}$ & 8,718 & 10,214 \\
$\mathrm{Cr}$ & 365 & 614 \\
$\mathrm{~Pb}$ & 3,270 & 3,720 \\
$\mathrm{Ni}$ & 252 & 1,311 \\
$\mathrm{Cd}$ & 2,269 & 614 \\
$\mathrm{Ba}$ & 1,890 & 2,094 \\
$\mathrm{Co}$ & 183 & 1,137 \\
$\mathrm{Mn}$ & 671 & $\mathrm{~N} . \mathrm{D}$ \\
$\mathrm{Fe}$ & 414 & 1,889 \\
$\mathrm{Mg}$ & 8,915 & 5,975 \\
$\mathrm{Ca}$ & 232,222 & 310,204 \\
$\mathrm{Cu}$ & 1,422 & 1,173 \\
$\mathrm{Ag}$ & 469 & 1,458 \\
$\mathrm{Al}$ & 16,407 & 15,617 \\
$\mathrm{Ga}$ & 111 & 506 \\
$\mathrm{Na}$ & 38,633 & 27,168 \\
$\mathrm{~K}$ & 21,837 & 19,071 \\
$\mathrm{Si}$ & 33,236 & 24,745 \\
$\mathrm{Cl}$ & 118,365 & 165,816 \\
\hline
\end{tabular}

D.L. $=0.1 \mathrm{mg} / \mathrm{L}$ and N.D. means the concentration of metal ion is below detection limit.

elemental composition measured in samples of the MSWI fly ash from plant A and B. The instrument detection limit (IDL) of the liquid extract was $0.1 \mathrm{mg} / \mathrm{L}$, which translates into a detection limit of $0.05 \mathrm{mg} / \mathrm{g}$ for the MSWI fly ash. All the values of metal concentration, $\mathrm{mg} / \mathrm{kg}$, are listed in Table 1 . The major elements in the MSWI fly ash from plant $\mathrm{A}$, in decreasing sequence, were $\mathrm{Ca}, \mathrm{Cl}, \mathrm{Na}, \mathrm{Si}$, $\mathrm{K}, \mathrm{Al}, \mathrm{Mg}$, and $\mathrm{Zn}$, while those from plant $\mathrm{B}$ (decreasing sequence) were $\mathrm{Ca}, \mathrm{Cl}, \mathrm{Na}, \mathrm{Si}, \mathrm{K}, \mathrm{Al}, \mathrm{Zn}$, and $\mathrm{Mg}$. The amounts of $\mathrm{Na}, \mathrm{Si}, \mathrm{K}$, and $\mathrm{Al}$ in the MSWI fly ash from plant A was higher than those from plant $\mathrm{B}$. However, the amounts of $\mathrm{Ca}, \mathrm{Cl}, \mathrm{Zn}$, and $\mathrm{Pb}$ from plant $\mathrm{B}$ was higher than those from plant $\mathrm{A}$. The higher amount of $\mathrm{Cl}$ was generated from the composition of refuse in the incineration processes. An amount of $\mathrm{HCl}$ was also generated. The higher amount of $\mathrm{Ca}$ was generated without $\mathrm{HCl} / \mathrm{SO}_{x}$ by the air pollution control device; the device adds excessive limestone to remove acidic gases. Several papers have reported a presence of $\mathrm{CaCl}_{2}, \mathrm{CaSO}_{4}, \mathrm{NaCl}, \mathrm{KCl}$, $\mathrm{Al}_{2} \mathrm{O}_{3}, \mathrm{SiO}_{2}$, etc. in MSWI fly ash [1,2] determine, which cause the fly ash to be alkaline ( $\mathrm{pH}$ value $>12$ ) because of the residual limestone.

Fig. 1(a) shows the XRD result of MSWI fly ash from plant A. There are amounts of $\mathrm{NaCl}, \mathrm{KCl}, \mathrm{CaClOH}, \mathrm{Ca}(\mathrm{OH})_{2}, \mathrm{~Pb}, \mathrm{AlO}, \mathrm{SiO}_{2}$, $\mathrm{PbO}_{2}$, and $\mathrm{KNO}_{3}$ in the MSWI fly ash, which supports the finding that the alkali in MSWI fly ash is caused by $\mathrm{CaClOH}$ and $\mathrm{Ca}(\mathrm{OH})_{2}$. In addition, there is a special phenomenon regarding the MSWI fly ash. The present study discovered that the reaction product of $\mathrm{Ca}$ and $\mathrm{Cl}$ is $\mathrm{CaClOH}$ and not $\mathrm{CaCl}_{2}$. The $\mathrm{CaClOH}$ seems to deposit the excess limestone in the air pollution control process in plant $\mathrm{A}$. At the same time, the $\mathrm{Al}$ species are $\mathrm{AlO}$ and not $\mathrm{Al}_{2} \mathrm{O}_{3}$. The results in Table 1 and Fig. 1(a) support the finding that the major contents of the MSWI fly ash from plant $\mathrm{A}$ are $\mathrm{NaCl}, \mathrm{KCl}, \mathrm{CaClOH}, \mathrm{Ca}(\mathrm{OH})_{2}, \mathrm{AlO}$, and $\mathrm{SiO}_{2}$.

Table 2 shows the chemical composition of MSWI fly ash from plant $A$ and $B$ after chemical sequential extraction. The fly ash from the two plants showed similar tendencies, and the chemical phase of compositions $(\mathrm{Zn}, \mathrm{Cr}, \mathrm{Pb}, \mathrm{Ca}$, and $\mathrm{Cu}$ ) for both plants was mainly oxide bound.

A result of TCLP leaching of MSWI fly ash (liquid to solid ratio $L / S=20$ ) from both plant $A$ and $B$, showed that the TCLP lead leaching concentrations for both raw and washed fly ash were much higher than the criterion in Taiwan $(5.0 \mathrm{mg} / \mathrm{L})$. The concentrations of $\mathrm{Zn}, \mathrm{Cr}, \mathrm{Pb}, \mathrm{Ca}$, and $\mathrm{Cu}$ ions from plant A were 14.29, 0.65, 49.10, 0.14 , and $0.45 \mathrm{mg} / \mathrm{L}$, respectively, while those from plant B were 6.11 , $0.63,74.58,0.14$, and $0.45 \mathrm{mg} / \mathrm{L}$, respectively. The concentrations of 


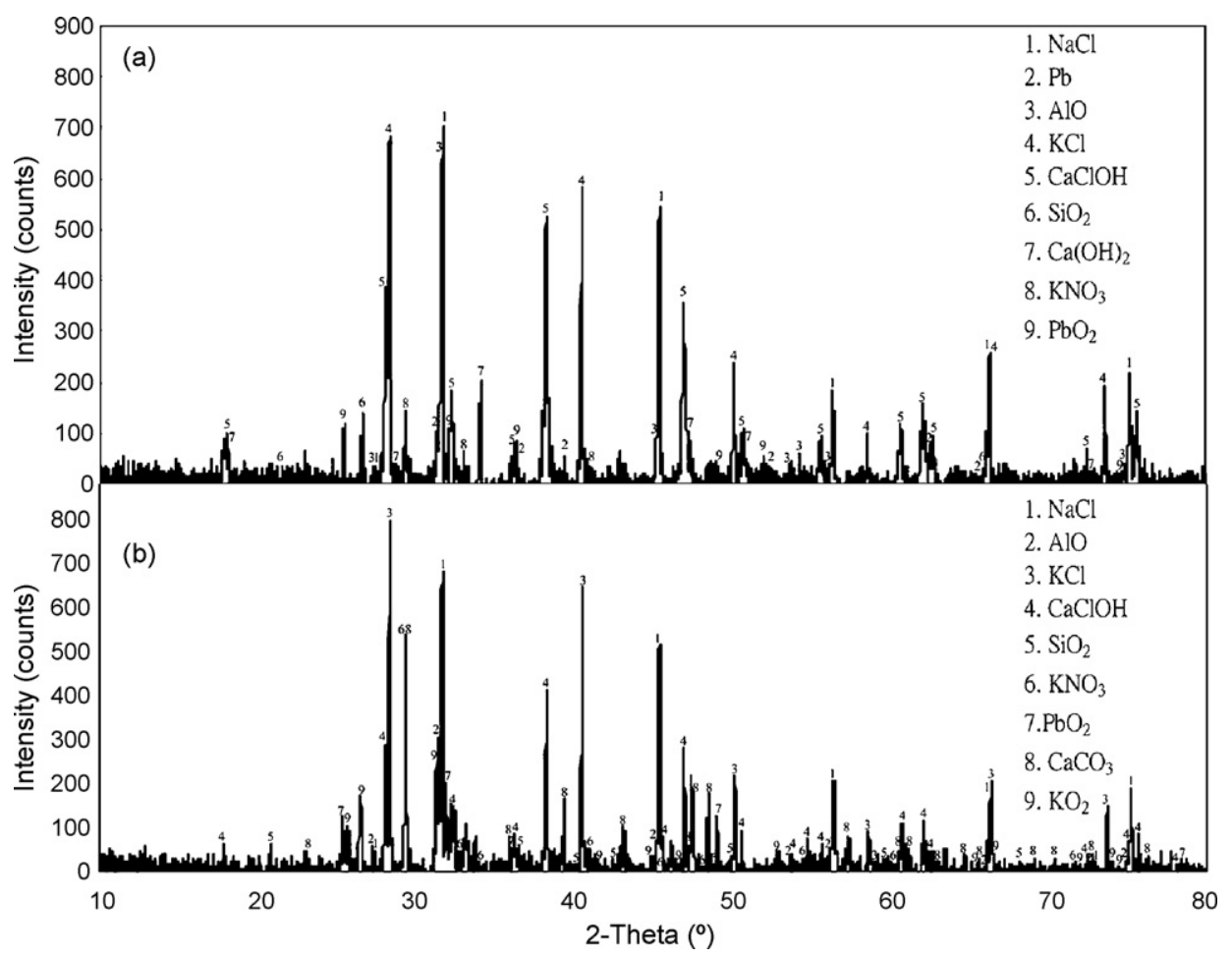

Fig. 1. XRD results of MSWI fly ash: (a) MSWI fly ash and (b) the sintered MSWI fly ash.

Table 2

Chemical composition of MSWI fly ash by chemical sequential extraction

\begin{tabular}{|c|c|c|c|c|c|c|c|c|c|c|}
\hline \multirow[t]{3}{*}{ Phase } & \multicolumn{10}{|c|}{ Elements (mg/kg) } \\
\hline & \multicolumn{2}{|l|}{$\mathrm{Zn}$} & \multicolumn{2}{|l|}{$\mathrm{Cr}$} & \multicolumn{2}{|l|}{$\mathrm{Pb}$} & \multicolumn{2}{|l|}{$\mathrm{Cd}$} & \multicolumn{2}{|l|}{$\mathrm{Cu}$} \\
\hline & Plant A & Plant B & Plant A & Plant B & Plant A & Plant B & Plant A & Plant B & Plant A & Plant B \\
\hline Exchangeable & 26.2 & 4.89 & 12.5 & 11.6 & 80.2 & 38.6 & 4.06 & 2.42 & 2.75 & 3.44 \\
\hline Carbonate bound & 5.96 & 5.13 & 10 & 15.6 & 29.2 & 24 & 2.22 & 2.57 & 2.55 & 2.13 \\
\hline Oxides bound & 6627 & 6048 & 145 & 101 & 2487 & 2623 & 160 & 164 & 465 & 112 \\
\hline Organic bound & 190 & 142 & 29.9 & 21.9 & 96.4 & 87.5 & 13.6 & 13.3 & 179 & 118 \\
\hline Residual & 266 & 231 & 26.3 & 23.3 & 48.2 & 45.9 & 12.2 & 12.2 & 37.8 & 41.8 \\
\hline
\end{tabular}

$\mathrm{Zn}, \mathrm{Cr}, \mathrm{Pb}, \mathrm{Ca}$, and $\mathrm{Cu}$ ions in the washed MSWI fly ash from plant A were $1.77,0.71,10.3,0.09$, and $0.18 \mathrm{mg} / \mathrm{L}$, respectively; the concentration of $\mathrm{Pb}$ ions was 10 times higher than the criterion in Taiwan $(5.0 \mathrm{mg} / \mathrm{L})$. Similar results had been reported before. In the light of these results, further treatment of MSWI fly ash is required before landfill disposal.

\subsection{TCLP concentration of heavy metals at different processing time}

Fig. 2 illustrates the effect of different processing time and TCLP concentration as follows: (1) the TCLP lead concentrations dropped dramatically with an increase in processing time after 20 min when the MSWI fly was sintered. (2) There was an obvious tendency in the TCLP zinc concentrations under microwave radiation. After 10 or 20 min under microwave radiation, the MSWI fly ash had not started to sinter yet; however, half of the MSWI fly ash had sintered after $30 \mathrm{~min}$, like Fig. 3(b). Most fly ash had sintered with minor part melting of the fly ash after $40 \mathrm{~min}$, like Fig. 3(c). All of the fly ash had sintered and stabilized after 50 min, like Fig. 3(d) and the crucibles cracked at these cases ( 40 and $50 \mathrm{~min}$ ). The TCLP leaching concentrations of lead were $107,121,69.1,2.43$, and $2.65 \mathrm{mg} / \mathrm{L}$ at 10 , $20,30,40$, and $50 \mathrm{~min}$, respectively.
The results illustrate that the TCLP lead, zinc, and copper concentrations dropped dramatically with an increase in processing time after the MSWI fly ash had started to sinter. Several researches have reported that the sintering of MSWI fly ash can generate a glass-ceramic material by conventional sinter treatment and decrease the TCLP leaching concentration of heavy metals [17,18].

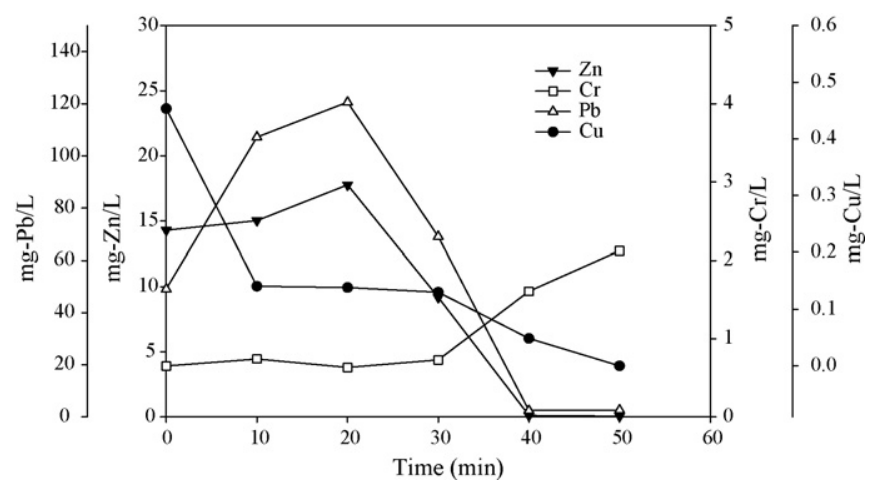

Fig. 2. The TCLP concentration of ions from the sintered MSWI fly ash (plant A) on the $\mathrm{SiO}_{2}$ ceramic crucible by microwave process. $(\boldsymbol{\nabla}) \mathrm{Zn},(\square) \mathrm{Cr},(\triangle) \mathrm{Pb}$, and $(\bullet) \mathrm{Cu}$. 


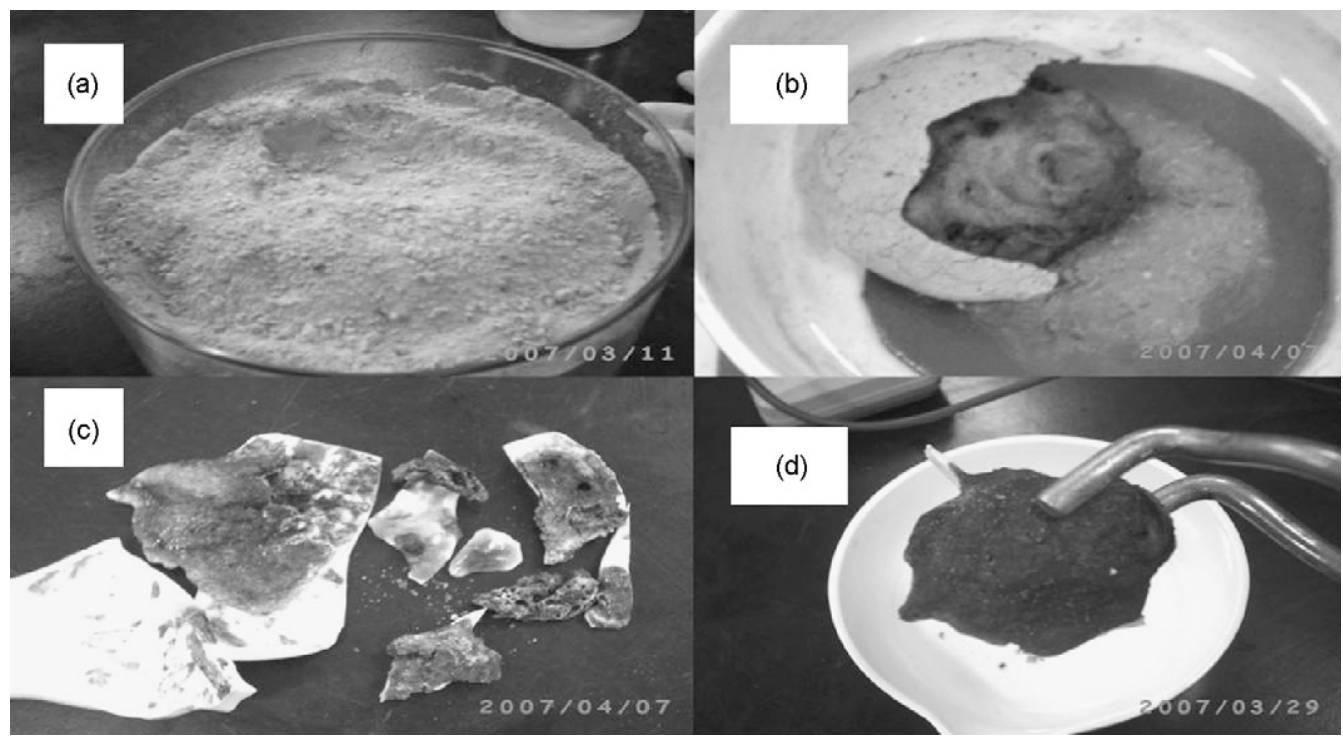

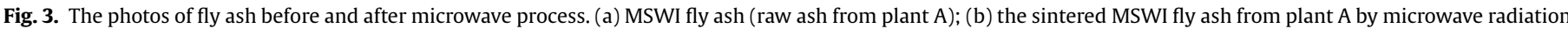

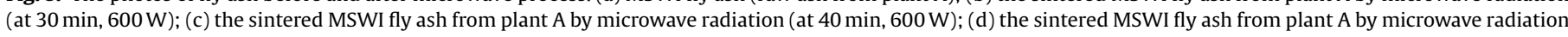
(at $50 \mathrm{~min}, 600 \mathrm{~W}$ ).

MSWI fly ash can also pass the criteria for heavy metals after it has been sintered. The results in Fig. 2 show that the sintering of MSWI fly ash decreased the TCLP leaching concentration of heavy metals. However, when the MSWI fly ash did not sinter, the TCLP leaching concentration of heavy metals increased.

No literature reports the sintering treatment of MSWI fly ash by microwave process was found; however, several papers report the use of a conventional sinter or vitrification for the treatment of MSWI fly ash. Also, many articles mention that these processes can generate a glass-ceramic or glassy material [18]. The sinter causes particles to bind and immobilize heavy metals [17]. This generates a glass-ceramic material and causes the immobilization of heavy metals. Under microwave radiation, the higher leaching resistance of the sintered glass-ceramics may be due to: (1) a well-dispersed discontinuous phase containing those heavy metals; (2) layered microstructure comprising a core highly loaded with heavy metals surrounded by a shell free from those hazardous metals; (3) gradient concentration of the inclusion phase containing those heavy metals.

Haque [4] reports that $\mathrm{Al}_{2} \mathrm{O}_{3}, \mathrm{Fe}_{3} \mathrm{O}_{4}, \mathrm{CuO}, \mathrm{Fe}_{2} \mathrm{O}_{3}$, and $\mathrm{C}$ can penetrate the dielectric region. Hirota et al. [7] refer to the thermal runaway phenomenon, which indicates that the absorption ability of materials is different at different temperatures; however, it rises dramatically with an increase in temperature. This is helpful in the sintering of MSWI fly ash. We consider that elements like water, $\mathrm{Al}_{2} \mathrm{O}_{3}, \mathrm{Fe}_{3} \mathrm{O}_{4}, \mathrm{CuO}, \mathrm{Fe}_{2} \mathrm{O}_{3}$, and $\mathrm{C}$ absorb microwave energy first, then the absorption ability of other materials is changed so they too absorb microwave energy. This causes the MSWI fly ash to sinter. The thermal runaway phenomenon causes hot spots and a dramatic temperature gradient; this in turn causes the crucible to crack, as the $\mathrm{SiO}_{2}$ ceramic crucible has poor heat conduction. Hirota et al. [7] found that the thermal runaway phenomenon caused samples to crack.

\subsection{Effect of different crucibles (containers)}

Graphite plate conducts heat well. In the present study, hot spots and the cracking of the crucible were at first avoided. Fig. 4 illustrates the effect of different containers and the following obser- vations were made under microwave radiation: (1) the TCLP lead concentrations dropped dramatically with a graphite plate $/ \mathrm{SiO}_{2}$ and $\mathrm{Al}_{2} \mathrm{O}_{3}$ ceramic crucible. (2) There was no obvious tendency with a graphite plate/SiC plate. MSWI fly ash on a graphite plate/SiC plate had not started to sinter after $10-50$ min under microwave processing $(600 \mathrm{~W})$. The TCLP leaching concentrations of lead in fly ash from plant A were 76.3, 71.9, 68.0,69.1, and $74.7 \mathrm{mg} / \mathrm{L}$ at 10, 20, 30,40 , and $50 \mathrm{~min}$, respectively. Its leaching concentrations were similar to that of the raw MSWI fly ash and 12 times higher than the criterion. However, MSWI fly ash sintered on a graphite plate $/ \mathrm{SiO}_{2}$ and an $\mathrm{Al}_{2} \mathrm{O}_{3}$ ceramic crucible had similar decreasing leaching concentrations. The TCLP lead leaching concentrations of MSWI fly ash from plant A and B would decrease with an increase of processing time under microwave radiation.

$\mathrm{SiC}$ has strong absorption ability for microwave radiation [4]. Therefore, SiC and MSWI fly ash would compete in absorbing

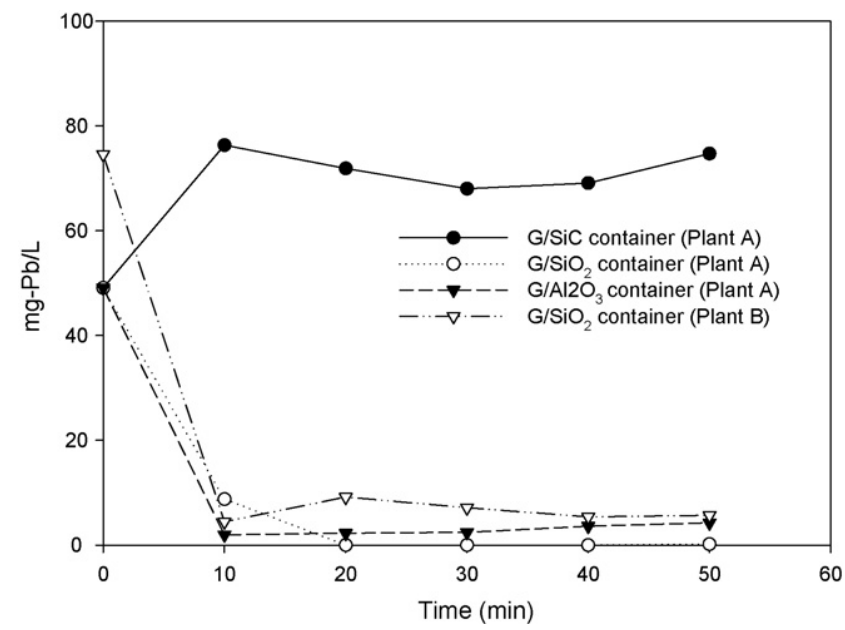

Fig. 4. The effect of different containers on the sintered MSWI fly ash by microwave process. (-) The MSWI fly ash from plant A on graphite plate/SiC plate, $(\bigcirc)$ the MSWI fly ash from plant A onto graphite plate $/ \mathrm{SiO}_{2}$ ceramic crucible, $(\boldsymbol{\nabla})$ the MSWI fly ash from plant $\mathrm{A}$ onto graphite plate $/ \mathrm{Al}_{2} \mathrm{O}_{3}$ ceramic crucible, and $(\nabla)$ the MSWI fly ash from plant $\mathrm{B}$ onto $\mathrm{SiO}_{2}$ ceramic crucible with graphite plate. 
Table 3

Pre-wash of MSWI fly ash with deionized water

\begin{tabular}{llccc}
\hline & \multicolumn{4}{l}{ Liquid/solid ratio } \\
\cline { 2 - 5 } & 5 & 10 & 15 & 20 \\
\hline Fly ash weight (g) & 20.0 & 10.0 & 6.67 & 5.01 \\
Residual ash after pre-wash (g) & 13.2 & 6.05 & 3.89 & 2.68 \\
Weight decrease (\%) & 33.9 & 39.6 & 41.7 & 46.5 \\
$\mathrm{pH}$ & 12.9 & 12.7 & 12.4 & 12.3 \\
\hline
\end{tabular}

Table 4

The concentration $(\mathrm{mg} / \mathrm{L})$ of leaching ions in pre-wash water

\begin{tabular}{lrrrr}
\hline Elements & \multicolumn{4}{r}{ Liquid/solid ratio } \\
\cline { 2 - 5 } & \multicolumn{1}{c}{5} & 10 & 15 & \multicolumn{1}{c}{20} \\
\hline $\mathrm{Pb}$ & 257 & 127 & 84 & 63 \\
$\mathrm{Ca}$ & 14,390 & 8,495 & 6,219 & 4,892 \\
$\mathrm{Na}$ & 4,235 & 2,733 & 1,807 & 1,278 \\
$\mathrm{~K}$ & 4,766 & 3,216 & 2,159 & 1,532 \\
$\mathrm{Cl}$ & 34,228 & 17,002 & 14,806 & 11,484 \\
\hline
\end{tabular}

the microwave energy when the SiC plate is used as container, and the MSWI fly ash would not sinter by microwave radiation. However, MSWI fly ash microwaved on a graphite plate $/ \mathrm{SiO}_{2}$ and an $\mathrm{Al}_{2} \mathrm{O}_{3}$ ceramic crucible did sinter. This is evidence that the absorption ability of SiC is better than that of MSWI fly ash.

\subsection{Effect of soluble salts and causticity for microwave sintering}

The results in Table 1 and Fig. 1(a) show that the major contents of the MSWI fly ash from plant A are $\mathrm{NaCl}, \mathrm{KCl}, \mathrm{CaClOH}$, and $\mathrm{Ca}(\mathrm{OH})_{2}$. This plays a role in sintering by microwave radiation. Deionized water (liquid to solid ratio $\mathrm{L} / \mathrm{S}=5,10,15$, and 20 ) was used to wash MSWI fly ash in advance. Table 3 shows the change in weight of MSWI fly ash due to the washing process. It appears that the leachate contained salts and causticity of $33.9 \%, 39.6 \%, 41.7 \%$, and $46.5 \%(\mathrm{w} / \mathrm{w})$, for the respective $\mathrm{L} / \mathrm{S}$ ratios, while the $\mathrm{pH}$ value is over 12 . Table 4 illustrates that there are abundant $\mathrm{Ca}, \mathrm{Na}, \mathrm{K}$, and $\mathrm{Cl}$ salts and caustic $\mathrm{Ca}$ and $\mathrm{K}$ in the leachate. In addition, the concentration of $\mathrm{Pb}$ ion was higher than the criterion in Taiwan $(5.0 \mathrm{mg} / \mathrm{L})$.

During the process of microwave treatment, the soluble salts and causticity played an important role in the sintering of MSWI fly ash of plant A. Fig. 5 shows the effect of soluble salts and causticity at the different $\mathrm{L} / \mathrm{S}$ ratios $(5,10,15$, and 20) in sintering. The MSWI fly ash in a graphite plate $/ \mathrm{SiO}_{2}$ ceramic crucible did not sinter under microwave radiation at $600 \mathrm{~W}$. This supports the postulation that soluble salts and causticity affect the sintering of MSWI fly ash by microwave radiation. Most of the TCLP lead leaching concentrations were higher than the criterion because the MSWI fly ash did not sinter. The sintering temperature in conventional thermal treatment can be decreased to $700-800^{\circ} \mathrm{C}$ when $\mathrm{NaCl}$ or $\mathrm{KCl}$ is present. This adds $\mathrm{Ca}(\mathrm{OH})_{2}, \mathrm{Na}_{2} \mathrm{O}$, or $\mathrm{K}_{2} \mathrm{O}$ which assist conventional sintering or vitrification. Kingman and Rowson [10] reported that molten caustic substances $(\mathrm{NaOH}$ and $\mathrm{KOH})$ were shown to be effective absorbers of microwave radiation and that they led to the accelerated differential heating of coal/pyrite phases.

\subsection{Aging}

Fig. 6 shows the aging of sintered MSWI fly ash from plant A during 0-30 days indoors with open system. The results showed

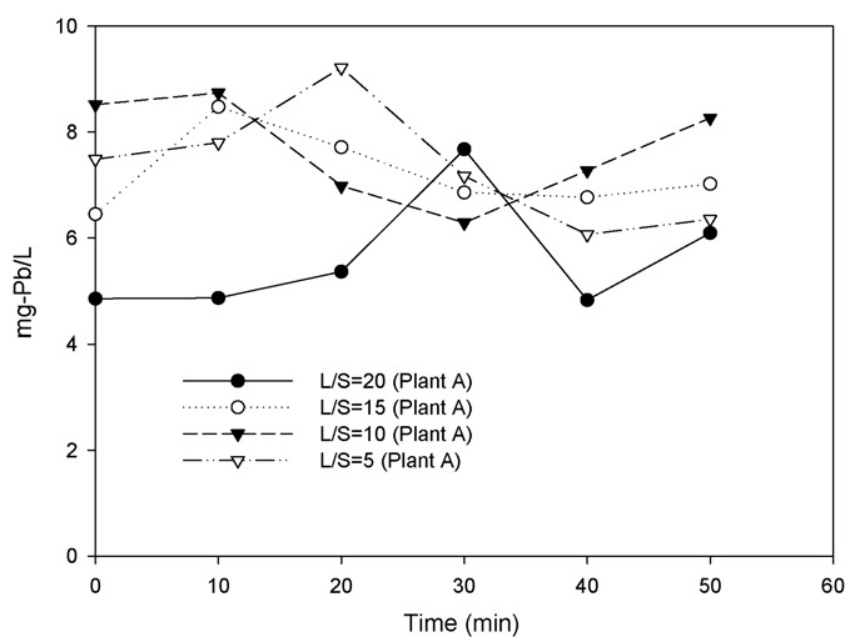

Fig. 5. The effect of soluble salt on microwave sintering. The MSWI fly ash from plant A: $(\bullet) \mathrm{L} / \mathrm{S}=20,(\bigcirc) \mathrm{L} / \mathrm{S}=15,(\boldsymbol{\nabla}) \mathrm{L} / \mathrm{S}=10,(\nabla) \mathrm{L} / \mathrm{S}=5$.

no obvious increase in TCLP lead leaching concentrations with an increase in time, and most of these concentrations were lower than the criterion. Fig. 6 illustrates that the lead ions can become immobile after microwave sintering, which can decrease the TCLP lead leaching concentrations. It was also found that the weight of sintered MSWI fly ash increased with an increase in aging time. It appears that the sintering of MSWI fly ash can bind particles to create a ceramic-like material which can restrain the leaching of heavy metals in MSWI fly ash [17].

There are amounts of $\mathrm{NaCl}, \mathrm{KCl}, \mathrm{CaClOH}, \mathrm{Ca}(\mathrm{OH})_{2}, \mathrm{~Pb}, \mathrm{AlO}, \mathrm{SiO}_{2}$, $\mathrm{PbO}_{2}$, and $\mathrm{KNO}_{3}$ in the MSWI fly ash from plant A. Fig. 1(b) shows the XRD diagram of sintered MSWI fly ash from plant A. It appears that there are $\mathrm{NaCl}, \mathrm{KCl}, \mathrm{AlO}, \mathrm{CaClOH}, \mathrm{SiO}_{2}, \mathrm{KNO}_{3}, \mathrm{PbO}_{2}, \mathrm{CaCO}_{3}$, and $\mathrm{KO}_{2}$ in the sintered MSWI fly ash; the $\mathrm{Pb}$ in the original fly ash was transformed into $\mathrm{PbO}_{2}$, the $\mathrm{Ca}(\mathrm{OH})_{2}$ into $\mathrm{CaCO}_{3}$, and the part of $\mathrm{KNO}_{3}$ into $\mathrm{KO}_{2}$.

$\mathrm{NaCl}, \mathrm{KCl}, \mathrm{CaClOH}, \mathrm{CaCO}_{3}$ and $\mathrm{KO}_{2}$ have a strong ability to absorb water vapor. This explains the weight increase of sintered MSWI fly ash with an increased aging time. In addition, the $\mathrm{Ca}(\mathrm{OH})_{2}$ in the original fly ash was transformed into $\mathrm{CaCO}_{3}$; for this there are two possible paths: (1) The carbon of MSWI fly ash forms into $\mathrm{CO}_{2}$ at first, then the $\mathrm{CO}_{2}$ and $\mathrm{Ca}(\mathrm{OH})_{2}$ react into $\mathrm{CaCO}_{3}$. (2) The $\mathrm{Ca}(\mathrm{OH})_{2}$ in the sintered MSWI fly ash absorbs $\mathrm{H}_{2} \mathrm{O}$ from the atmosphere, then

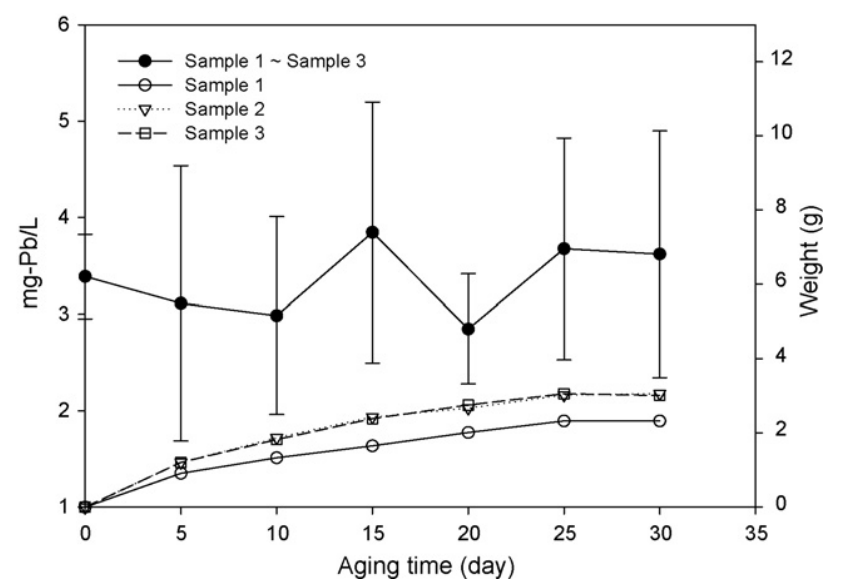

Fig. 6. The TCLP leaching concentration of $\mathrm{Pb}$ (MSWI fly ash from plant A) at different aging times. Leaching concentration $(\bullet)$ average of samples $1-3$, and weight variation: $(\bigcirc)$ sample $1,(\nabla)$ sample 2 , and $(\square)$ sample 3. 
the $\mathrm{CO}_{2}$ dissolves in the water. Finally, the carbonate and $\mathrm{Ca}(\mathrm{OH})_{2}$ react into $\mathrm{CaCO}_{3}$.

\section{Conclusion}

This study of the sintering of MSWI fly ash by microwave radiation led to the following conclusions:

1. The $\mathrm{Zn}, \mathrm{Cr}, \mathrm{Pb}, \mathrm{Ca}$, and $\mathrm{Cu}$ in the fly ash were mainly in oxide phase and only the leaching concentration of $\mathrm{Pb}$ was higher than the criterion of TCLP.

2. The MSWI fly ash could be sintered under microwave processing which could immobilize heavy metals and form a glass-ceramic material. The sintering efficiency increased as the microwave time was longer.

3. MSWI fly ash was effectively sintered by using graphite plate $/ \mathrm{SiO}_{2}$ container under microwave radiation when compared with the case of graphite plate/SiC plate. The SiC plate would compete with the MSWI fly ash in absorbing the microwave energy.

4. The pre-wash process before microwave process would leach out the soluble salt and causticity in the fly ash leading to the decreasing of sintering efficiency.

5. Aging of sintered MSWI fly ash during 0-30 days showed no obvious increase in the TCLP Pb leaching concentrations, and most of these concentrations were lower than the criterion $(5 \mathrm{mg} / \mathrm{L})$. This illustrates that the lead ions can be immobilized by microwave sintering. However, the sintered MSWI fly ash may adsorb the water content in the air leading to the weight increase of $40-60 \%$.

\section{Acknowledgement}

The authors convey their gratitude to the Ministry of Economic Affairs of the Republic of China (Contract No.: 96-EC-17-A-10-S10007) for financial support.

\section{References}

[1] C.C. Wiles, Municipal solid waste combustion ash: state-of-the-knowledge, J. Hazard. Mater. 47 (1996) 325-344

[2] H. Katsuura, T. Inou, M. Hiraoka, S. Sakai, Full-scale plant study on fly ash treatment by the acid extraction process, Waste Manage. 16 (5/6) (1996) 491-499.

[3] J.E. Aubert, B. Husson, A. Vaquier, Use of municipal solid waste incineration fly ash in concrete, Cement Concrete Res. 34 (2004) 957-963.

[4] K.E. Haque, Microwave energy for mineral treatment processes-a brief review, Int. J. Miner. Process. 57 (1999) 1-24.

[5] E. Siores, D.D. Rego, Microwave applications in materials joining, J. Mater. Process. Technol. 48 (1995) 619-625.

[6] D.K. Agrawal, Microwave processing of ceramics, Curr. Opin. Solid-State Mater. Sci. 3 (1998) 480-485.

[7] M. Hirota, M.C. Valecillos, M.E. Brito, K. Hirota, M. Toriyama, Grain growth in millimeter wave sintered silicon nitride ceramics, J. Eur. Ceram. Soc. 24 (2004) 3337-3343.

[8] E. Sedhom, L. Dauerman, N. Ibrahim, G. Windgasse, Microwave treatment of hazardous wastes: "fixation" of chromium in soil, J. Microwave Power Electromagn. Energy 27 (2) (1992) 81-86.

[9] D.A. Jones, T.P. Lelyveld, S.D. Mavrofidis, S.W. Kingman, N.J. Miles, Microwave heating applications in environmental engineering-a review, Resour. Conserv. Recycl. 34 (2002) 75-90.

[10] Kingman FS.W., N.A. Rowson, Microwave treatment of minerals-a review, Miner. Eng. 11 (11) (1998) 1081-1087.

[11] T.J. Appleton, R.I. Gloder, S.W. Kingman, I.S. Lowndes, A.G. Read, Microwave technology for energy-efficient processing of waste, Appl. Energy 81 (2005) 85-113.

[12] K.J. Lamble, S.J. Hill, Critical review-microwave digestion procedures for environmental materials, Analyst 123 (1998) 103R-133R.

[13] Q. Gan, A case study of microwave processing of metal hydroxide sediment sludge from printed circuit board manufacturing wash water, Waste Manage. 20 (2000) 695-701.

[14] C.L. Chen, S.L. Lo, W.H. Kuan, C.H. Hsieh, Stabilization of $\mathrm{Cu}(\mathrm{II})$ in acid extracted industrial sludge using a microwave process, J. Hazard. Mater. B 123 (2005) 256-261.

[15] C.H. Hsieh, S.L. Lo, P.T. Chiueh, W.H. Kuan, C.L. Chen, Microwave enhanced reclamation of heavy metal sludge, J. Hazard. Mater. B 139 (2007) 160-166.

[16] A. Tessier, P.G.C. Campbell, M. Bisson, Sequential extraction procedure for the speciation of particulate trace metals, Anal. Chem. 51 (7) (1979) 844-850.

[17] K.S. Wang, C.J.Sun, C.C. Yeh, The thermotreatment of MSW incinerator fly ash for use as aggregate: a study of the characteristics of size-fraction, Resour. Conserv. Recycl. 35 (2002) 325-344

[18] R.D. Rawlings, J.P. Wu, A.R. Boccaccini, Glass-ceramics: their production from wastes. A review, J. Mater. Sci. 41 (2006) 733-761. 